\title{
Endoscopic stag beetle knife treatment for symptomatic Zenker's diverticulum
}

Zenker's diverticulum is a pulsion diverticulum that develops through Killian's triangle, an area of weakness of the posterior hypopharynx. The reported prevalence of Zenker's diverticulum is between $0.01 \%$ and $0.11 \%$, and it is typically seen in middle-aged and older male patients in their seventh or eighth decade of life [1]. Diagnosis is based on clinical symptoms such as dysphagia, the predominant symptom in $80 \%$ to $90 \%$ of patients. The diagnosis of Zenker's diverticulum is made on a barium swallow examination. Upper endoscopy is not required to confirm the diagnosis but is recommended to exclude malignancy [2].

Flexible endoscopic treatment, preferred over open surgical treatment, is the firstline therapy for patients with a symptomatic Zenker's diverticulum of any size [3]. In all, three options are available for treatment: open surgery, rigid endoscopy, and flexible endoscopy. Thanks to flexible endoscopy, many techniques have emerged in recent years, such as Zenker's diverticulum peroral endoscopic myotomy (Z-POEM). Besides that, some tools have been adapted to perform safe and effective septotomy.

The stag beetle (SB) knife (Sumimoto Bakelite Ltd.) is a scissor-shaped, rotating device with two insulated monopolar blades designed primarily for endoscopic submucosal dissection (ESD). Battaglia et al. [4] and Goelder et al. [5] demonstrated that the SB knife is a safe and effective alternative for treating symptomatic Zenker's diverticulum.

A 69-year-old woman presented with dysphagia. Her symptoms had started 3 years earlier. A barium swallow examination was performed and Zenker's diverticulum was diagnosed ( $\triangleright$ Fig.1). Zenker's diverticulotomy was performed with the patient under general anesthesia. We used a 9.8-mm diameter endoscope, an SB knife, a distal attachment cap, a metallic clip (HX-610-135; Olympus, Japan), and a nasoenteral feeding tube.

First, we passed the nasoenteral feeding tube through the esophagus. After grasp-
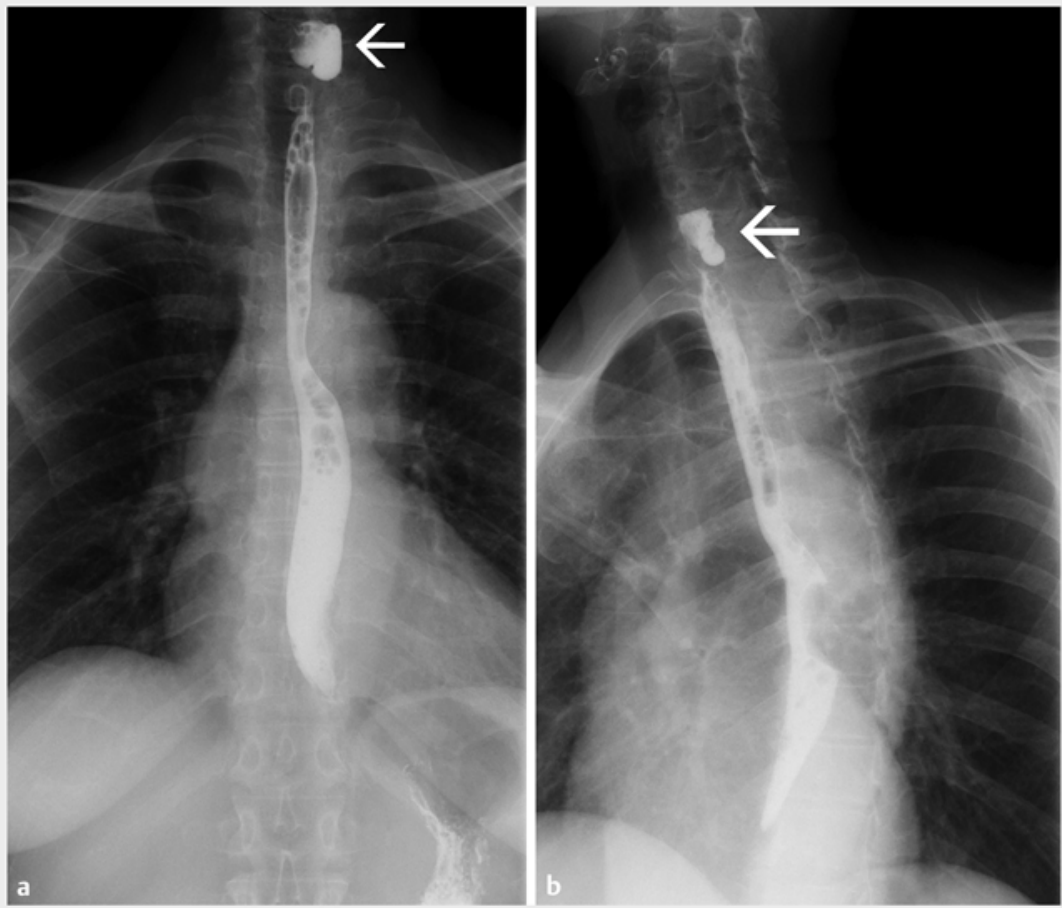

Fig. 1 Barium study demonstrates a $1.7-\times 1.0-\mathrm{cm}$ diverticulum arising from the posterior wall of the upper esophagus.
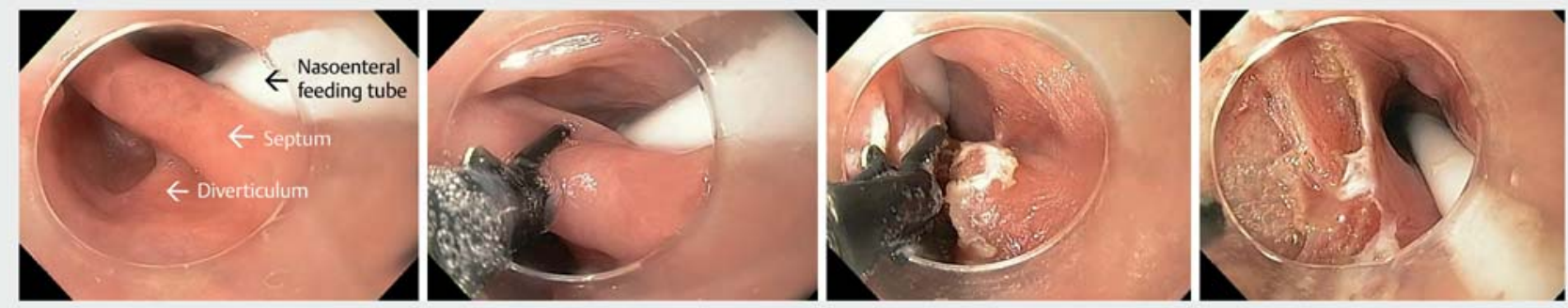

- Fig. 2 Endoscopic views, left to right: before the procedure; stag beetle (SB) knife grasping the septum; septum division using the SB knife; after septum division. 


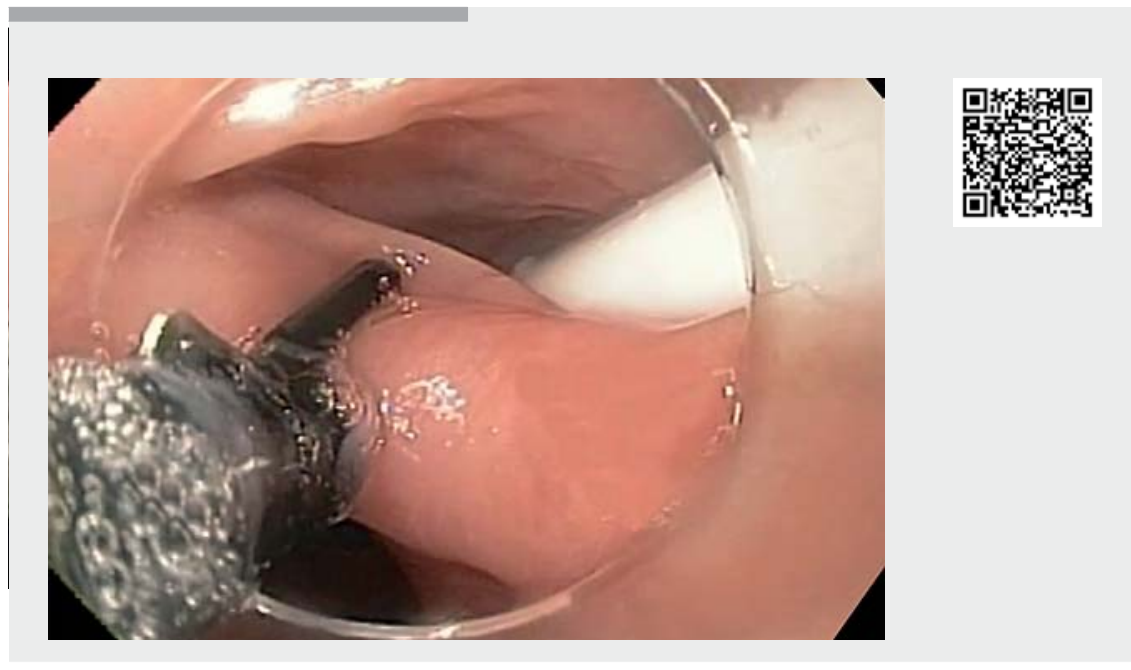

$\checkmark$ Video 1 Endoscopic stag beetle knife treatment for symptomatic Zenker's diverticulum: a safe and feasible approach.

ing the mucosa, we applied a burst of coagulation current before grasping the tissue and dissecting it with Endo Cut Q, effect 3 (Erbe V300 D). We deployed the clip to prevent mucosal dissection and perforation ( $>$ Fig. 2 ). The procedure was completed without adverse events ( $\vee$ Video 1). The patient was discharged on the first postoperative day receiving liquids and enteral nutrition. After 7 days, the nasoenteral feeding tube was removed and the patient started a soft diet with no symptoms, and she remains without symptoms until the present date.

Endoscopy_UCTN_Code_TTT_1AO_2AN

Competing interests

The authors declare that they have no conflict of interest.

The authors

Epifanio Silvino do Monte, Edson Ide, Vitor Massaro Takamatsu Sagae, Igor Braga Ribeiro, Mateus Pereira Funari, Pedro Victor Aniz Gomes de Oliveira, Eduardo Guimarães Hourneaux de Moura

Gastrointestinal Endoscopy Unit, Hospital das Clínicas da Faculdade de Medicina da Universidade de São Paulo, São Paulo, Brazil

\section{Corresponding author}

\section{Igor Braga Ribeiro, MD}

Gastrointestinal Endoscopy Unit, Hospital das Clínicas da Faculdade de Medicina da Universidade de São Paulo, Av. Dr Enéas de Carvalho Aguiar, 225, 6o, andar, bloco 3, Cerqueira Cesar, ZIP Code 05403-010 São Paulo, SP, Brazil Fax: +55-11-26616467

\section{References}

[1] Verhaegen VJO, Feuth T, van den Hoogen FJA et al. Endoscopic carbon dioxide laser diverticulostomy versus endoscopic stapleassisted diverticulostomy to treat Zenker's diverticulum. Head Neck 2011; 33: 154159. http://www.ncbi.nlm.nih.gov/ pubmed/20848433

[2] Pang M, Koop A, Brahmbhatt B et al. Comparison of flexible endoscopic cricopharyngeal myectomy and myotomy approaches for Zenker diverticulum repair. Gastrointest Endosc 2019; 89: 880-886. http://www. ncbi.nlm.nih.gov/pubmed/30342027

[3] Weusten BLAM, Barret M, Bredenoord AJ et al. Endoscopic management of gastrointestinal motility disorders - part 2: European Society of Gastrointestinal Endoscopy (ESGE) Guideline. Endoscopy 2020; 52: 600614. http://www.ncbi.nlm.nih.gov/ pubmed/32462649

[4] Battaglia G, Antonello A, Realdon S et al. Flexible endoscopic treatment for Zenker's igorbraga1@gmail.com diverticulum with the SB Knife. Preliminary results from a single-center experience. Dig Endosc 2015; 27: 728-733. http://www. ncbi.nlm.nih.gov/pubmed/25975384

[5] Goelder SK, Brueckner J, Messmann H. Endoscopic treatment of Zenker's diverticulum with the stag beetle knife (sb knife) feasibility and follow-up. Scand J Gastroenterol 2016; 51: 1155-1158. http://www. ncbi.nlm.nih.gov/pubmed/27218662

Bibliography

Endoscopy 2021; 53: E318-E319

DOI 10.1055/a-1273-7390

ISSN 0013-726X

published online 19.10.2020

(C) 2020. Thieme. All rights reserved.

Georg Thieme Verlag KG, Rüdigerstraße 14,

70469 Stuttgart, Germany

\section{ENDOSCOPY E-VIDEOS}

https://eref.thieme.de/e-videos

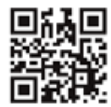

Endoscopy E-Videos is a free access online section, reporting on interesting cases and new

techniques in gastroenterological endoscopy. All papers include a high quality video and all contributions are freely accessible online.

This section has its own submission website at https://mc.manuscriptcentral.com/e-videos 